\title{
Mutational analysis of TAC3 and TACR3 genes in patients with idiopathic central pubertal disorders
}

\author{
Análise de mutações nos genes TAC3 e TACR3 em pacientes \\ com distúrbios puberais centrais idiopáticos
}

Cintia Tusset', Sekoni D. Noel², Ericka B. Trarbach', Letícia F. G. Silveira', Alexander A. L. Jorge' ', Vinicius N. Brito', Priscila Cukier', Stephanie B. Seminara ${ }^{3}$, Berenice B. de Mendonça', Ursula B. Kaiser'², Ana Claudia Latronico'

\footnotetext{
1 Unidade de Endocrinologia do Desenvolvimento, Laboratório de Hormônios e Genética Molecular/ LIM42, Hospital das Clínicas da Faculdade de Medicina da Universidade de São Paulo (HCFMUSP), São Paulo, SP, Brazil 2 Harvard Center for Reproductive Sciences and Division of Endocrinology, Diabetes, and Hypertension, Brigham and Women's Hospital, Boston, MA, United States

${ }^{3}$ Harvard Center for Reproductive Sciences and Reproductive Endocrine Unit, Department of Medicine, Massachusetts General Hospital, Boston, MA, United States
}

\begin{abstract}
Objective: To investigate the presence of variants in the TAC3 and TACR3 genes, which encode NKB and its receptor (NK3R), respectively, in a large cohort of patients with idiopathic central pubertal disorders. Subjects and methods: Two hundred and thirty seven patients were studied: 114 with central precocious puberty (CPP), 73 with normosmic isolated hypogonadotropic hypogonadism $(\mathrm{IHH})$, and 50 with constitutional delay of growth and puberty (CDGP). The control group consisted of 150 Brazilian individuals with normal pubertal development. Genomic DNA was extracted from peripheral blood and the entire coding region of both TAC3 and TACR3 genes were amplified and automatically sequenced. Results: We identified one variant ( $p . A 63 P)$ in NKB and four variants, p.G18D, p.L58L (c.172C > T), p.W275* and p.A449S in NK3R, which were absent in the control group. The p.A63P variant was identified in a girl with CPP, and p.A449S in a girl with CDGP. The known p.G18D, p.L58L, and p.W275* variants were identified in three unrelated males with normosmic IHH. Conclusion: Rare variants in the TAC3 and TACR3 genes were identified in patients with central pubertal disorders. Loss-of-function variants of TACR3 were associated with the normosmic IHH phenotype. Arq Bras Endocrinol Metab. 2012;56(9):646-52
\end{abstract}

\section{Keywords}

Neurokinin B; neurokinin B receptor; central precocious puberty; normosmic isolated hypogonadotropic hypogonadism; constitutional delay of growth and puberty

\section{RESUMO}

Objetivo: Investigar a presença de variantes nos genes TAC3 e TACR3, os quais codificam a NKB e seu receptor (NK3R), respectivamente, em uma coorte de pacientes com distúrbios puberais centrais idiopáticos. Sujeitos e métodos: Duzentos e trinta e sete pacientes foram estudados: 114 com puberdade precoce central (PPC), 73 com hipogonadismo hipogonadotrófico isolado normósmico (HHI) e 50 com retardo constitucional do crescimento e desenvolvimento (RCCD). 0 grupo controle consistiu de 150 indivíduos brasileiros que apresentaram desenvolvimento puberal normal. O DNA genômico foi extraído de sangue periférico, e as regiões codificadoras dos genes TAC3 e TACR3 foram amplificadas e sequenciadas automaticamente. Resultados: Uma variante (p.A63P) foi identificada na NKB, e quatro variantes, p.G18D, p.L58L (c.172C>T), p.W275X e p.A449S, foram identificadas no NK3R, as quais foram ausentes no grupo controle. A variante p.A63P foi identificada em uma menina com PPC, e a variante p.A449S, em uma menina com RCCD. As variantes previamente descritas, p.G18D, p.L58L e p.W275X, foram identificadas em três indivíduos com $\mathrm{HHI}$ normósmico do sexo masculino não relacionados. Conclusão: Variantes raras nos genes TAC3 e TACR3 foram identificadas em pacientes com distúrbios puberais centrais idiopáticos. Mutações de perda de função no gene TACR3 foram associadas com o fenótipo de HHI normósmico. Arq Bras Endocrinol Metab. 2012;56(9):646-52

\section{Descritores}

Neurocinina B; receptor da neurocinina B; puberdade precoce central; hipogonadismo hipogonadotrófico isolado normósmico; retardo constitucional do crescimento e desenvolvimento 


\section{INTRODUCTION}

$\mathrm{N}$ eurokinin $B(\mathrm{NKB})$ is a member of the mammalian tachykinin family of peptides, classified as neurotransmitters that include substance $\mathrm{P}$, neurokinin $A$, neurokinin $B$, as well as neuropeptide $K$, neuropeptide $\gamma$, and hemokinin-l (1). Recent advances in the field of tachykinins have considerably increased interest in this peptide family (2). Anatomical, neurochemical, and pharmacological evidence suggest that these peptides could play a role as mediators of nonadrenergic and noncholinergic excitatory neurotransmission (3-5). Tachykinins interact with three distinct types of receptors termed NK1R, NK2R, and NK3R, which are preferentially activated by $\mathrm{SP}, \mathrm{NKA}$, and $\mathrm{NKB}$, respectively (2). In humans, NKB and its receptor are encoded by the TAC3 and TACR 3 genes, respectively $(1,6)$.

The neurokinin $B$ system has recently been implicated in the regulation of the human reproductive axis, following the identification of inactivating mutations in TAC3 and TACR 3 genes in patients with normosmic isolated hypogonadotropic hypogonadism (IHH) (7). In a seminal study, Topaloglu and cols. (7) identified a critical role for NKB in human reproduction using genome-wide SNP analysis in nine inbred Turkish families with multiple members affected with normosmic IHH (7). In this study, rare missense variants in the TAC3 and TACR 3 genes were described in four of these families with normosmic IHH (7). This first report implicated NKB signaling as an essential component for the onset of puberty and the control of gonadotropin secretion in humans (1). To date, approximately 50 individuals with TAC3 and TACR 3 mutations have been described, with a worldwide distribution and a diverse racial mix (7-12). Recently, we reported that mutations in the NKB system occurred in more than $5 \%$ of a normosmic IHH population (10).

The mechanism whereby the NKB system exerts its effects on the central neuroendocrine control of human reproduction remains unknown (13). Several lines of evidence suggest that neurokinin $\mathrm{B}$ might have a role as a regulator of $\mathrm{GnRH}$ secretion (14). Furthermore, animal studies demonstrated that Kissl neurons of the arcuate nucleus coexpress NKB and dynorphin (Dyn) (14-16). These neurons were also confirmed to coexpress NK3R, suggesting a role in coordinating the activity of $\mathrm{NKB} /$ Dyn/Kisspeptin neurons of the arcuate nucleus.

Kisspeptin receptor and its ligand, kisspeptin, have been considered as major gatekeepers of puberty onset (17). Teles and cols. (18) reported a first activating mutation in the kisspeptin receptor (p.R386P) in an adopted Brazilian girl with central precocious puberty (18). More recently, Silveira and cols. (19) identified one new rare variant in the kisspeptin (p.P74S) in one boy with sporadic central precocious puberty. Therefore, it is also reasonable to hypothesize that gain-offunction mutation in TACR3, encoding a G proteincoupled receptor, might be identified in children with central precocious puberty (13). In this study, we investigated the presence of activating variants in the TAC3 and TACR 3 genes in a large group of patients with idiopathic central precocious puberty. We also searched for inactivating variants in additional patients with normosmic IHH, as well as in patients with constitutional delay of growth and puberty.

\section{MATERIALS AND METHODS}

\section{Patients}

Two hundred and thirty seven patients with central pubertal disorders were studied: 114 with central precocious puberty (CPP), 73 with normosmic isolated hypogonadotropic hypogonadism ( $\mathrm{IHH})$, and 50 with constitutional delay of growth and puberty (CDGP) (Table 1). Sixty IHH patients were previously reported (10). All patients were evaluated at Universidade de Sao Paulo (USP), except 26 North American patients with CPP who were referred to Harvard Medical School. Informed written consent was obtained from all patients, and the study was approved by the Ethics Committee of the Hospital das Clinicas, Universidade de Sao Paulo. FGFRl, FGF8, GNRHI, GNRHR, KISSIR, KISS1, PROK2, and PROKR2 genes were previously studied in the cohort of patients with IHH. In addition, GNRHR, KISSIR, KISSI, and LIN28B genes were previously studied in Brazilian patients with CPP. The control population consisted of 150 healthy Brazilian individuals of both genders with normal $\mathrm{pu}^{-}$ bertal development.

The diagnosis of central precocious puberty was based on the following criteria: puberty onset before eight years of age in girls and nine years of age in boys, pubertal LH levels (basal and/or after an acute GnRH stimulation test), and normal central nervous system magnetic resonance imaging (MRI).

The diagnosis of normosmic IHH was based on incomplete or absent pubertal development after 18 years, prepubertal or low testosterone or estradiol levels for the age, low or normal basal gonadotropin levels but 
Table 1. Clinical features at the time of diagnosis of the Brazilian patients with idiopathic central pubertal disorders

\begin{tabular}{lccc}
\hline Disorder & CPP & IHH & CDPG \\
\hline Number of patients & 114 & 73 & 50 \\
Gender & 107 girls/7 boys & 26 women/47 men & 11 girls/39 boys \\
Chronological age & $5.2 \pm 2.1$ & $23.8 \pm 8.1$ & $14.8 \pm 1.4$ \\
Bone age & $9.7 \pm 2.5$ & $14.5 \pm 2.2$ & $11.8 \pm 1$ \\
Basal LH (IU/L) & $1.5 \pm 1.7$ & $1.4 \pm 2.1$ & $1.0 \pm 0.6$ \\
Peak LH (IU/L) & $17.9 \pm 13.6$ & - & - \\
FSH (IU/L) & $3.5 \pm 1.9$ & $1.9 \pm 1.8$ & $2.0 \pm 1.1$ \\
Testosterone (ng/dL) & $280.0 \pm 235.0$ & $45.0 \pm 33.0$ & $65.0 \pm 71.0$ \\
Estradiol (pg/mL) & $56.6 \pm 19.8$ & $37.0 \pm 23.1$ & $48.0 \pm 41.0$ \\
\% Familial & $19.4 \% 1$ & $16.4 \%$ & $22 \%$ \\
\hline
\end{tabular}

CPP: central precocious puberty; IHH: isolated hypogonadotropic hypogonadism; CDGP: constitutional delay of growth and puberty. The complete hormonal data were available for 76 Brazilian patients with CPP (72 girls and 4 boys), 59 patients with normosmic IHH (21 women and $38 \mathrm{men}$ ), and 50 patients with CDGP (11 girls and 39 boys). ${ }^{1}$ Hormonal analyses of male patients. ${ }^{2}$ Hormonal analyses of female patients. Peak LH: LH after acute GnRH stimulation test. IFMA (Immunofluorometric method). Reference ranges (IFMA): FSH (prepubertal girls and boys $\leq 3.2 \mathrm{IU} / \mathrm{L}$; adult males 2.9-7.8 $\mathrm{IU} / \mathrm{L}$ and adult women (follicular phase) 2.4-9.3 $\mathrm{IU} / \mathrm{L}) ; \mathrm{LH}$ (prepubertal girls and boys $\leq 0.6 \mathrm{IU} / \mathrm{L}$; adult males 1.0-8.4 IU/L and adult females (follicular phase) 2.2-6.8 U/L); Testosterone (prepubertal boys $<14 \mathrm{ng} / \mathrm{dL}$ and adult males $200-950 \mathrm{ng} / \mathrm{dL}$ ); Estradiol (prepubertal girls $<21 \mathrm{pg} / \mathrm{mL}$ and adult women (follicular phase) $22-215 \mathrm{pg} / \mathrm{mL})$.

otherwise normal pituitary function, and normal hypothalamic-pituitary imaging. The diagnosis of CDGP was based on lack of breast development (Tanner stage 2 ) by the age of 13 and absent menarche by the age of 15 years in girls, and testicular volume $<4.0 \mathrm{~mL}$ by the age of 14 years in boys, absence of other identifiable causes of delayed puberty, delayed bone age, as well as spontaneous and complete achievement of pubertal development by age 18 years, during follow-up.

\section{DNA analysis}

Genomic DNA was extracted from peripheral blood leukocytes using standard procedures. The entire coding regions and the intron-exon junctions of TAC3 (GenBank accession number - MIM162330) and TACR3 (GenBank accession number - MIM162332) genes were amplified by polymerase chain reaction using specific primers, and were automatically sequenced (Table 2).

Amplification reactions were performed in a final volume of $25 \mu \mathrm{L}$ containing $200 \mathrm{ng}$ genomic DNA, $0.2 \mathrm{mM}$ dNTPs, $1.5 \mathrm{mM}$ PCRx Enhancer Solution (Invitrogen), 0.6 pmol each primer, IX PCR buffer, and IU Go Taq DNA polymerase (Promega, Madison, WI), and were carried out for 35 cycles: denaturation at $95^{\circ} \mathrm{C}$ for $30 \mathrm{~s}$, annealing at $55-56^{\circ} \mathrm{C}$ for $30 \mathrm{~s}$, exten-
Table 2. Oligonucleotide sequences and annealing temperature $\left({ }^{\circ} \mathrm{C}\right)$ of TAC3 and TACR3 genes PCR

\begin{tabular}{|c|c|c|c|}
\hline Gene & Exon & Oligonucleotide sequence & $\begin{array}{l}\text { Annealing } \\
\text { temp }\left({ }^{\circ} \mathrm{C}\right)\end{array}$ \\
\hline \multirow[t]{10}{*}{ TACR3 } & 1 & 1F 5'CAGGGATTGCAGTATCTTTC 3' & 55 \\
\hline & & 1R 5'CCTCCTTTCAGCAAAAATTC3' & \\
\hline & 2 & 2F 5'GCCATGATTACCATTCTACG3' & 56 \\
\hline & & 2R 5'ACTTATTGACCACACACAAATC3' & \\
\hline & 3 & 3F 5'CAACTGGCAGCATTTGAAAC3' & 56 \\
\hline & & 3R 5'gattacagtatgtggacagcagc3' & \\
\hline & 4 & 4F 5'CTGTCCGTATATTGCTTCACC3' & 55 \\
\hline & & 4R 5'AAGCCTGTGCCTCTCTCAG3' & \\
\hline & 5 & 5F 5'TGACATAAATTCTAAGAGTCTGG3’ & 55 \\
\hline & & 5R 5'CTTTCTCAATTTGACCATAGC3' & \\
\hline \multirow[t]{6}{*}{ TAC3 } & 2 & 2F 5'CAAGCTGCTGGTAATGAATG3' & 55 \\
\hline & & 2R 5'AAATGCCCTCTGACGGAC3’ & \\
\hline & 3 and 4 & 34F 5'GATTCAGGATGGGCTCAGG3' & 55 \\
\hline & & 34R 5'GGGAGCTGGCATATTGTTTG3' & \\
\hline & 5 and 6 & 56F 5'GAACAGAGACCAGAAACCCAGTC3' & 56 \\
\hline & & 56R 5'TTTAATACCTGTAGCATGGGAGGAA3’ & \\
\hline
\end{tabular}

F: forward; R: reverse.

sion at $72^{\circ} \mathrm{C}$ for $1 \mathrm{~min}$, followed by a final extension for $10 \mathrm{~min}$ at $72^{\circ} \mathrm{C}$. The PCR products were checked on $1 \%$ agarose gel electrophoresis, purified and automatically sequenced in an ABI Prism Genetic Analyzer 3100 automatic DNA sequencer (Applied Biosystems, Foster City, CA). All sequence variations were found on both strands and confirmed in a second PCR reaction.

\section{In silico analyses}

All mutations were analyzed using NNSPLICE 0.9 and Human Splice Finder to evaluate if these mutations could create or disrupt splice sites or auxiliary (enhancer or silencer) cis-splicing sequences. In addition, Polyphen-2 and SIFT were utilized to predict the potential impact of non-synonymous amino acid substitutions (missense variants) on protein structure and activity.

\section{RESULTS}

\section{Central precocious puberty}

Sequencing of the TAC3 gene revealed a heterozygous $\mathrm{G}$ to $\mathrm{C}$ transversion in coding nucleotide 187 $($ c. $187 \mathrm{G}>\mathrm{C})$ in a Brazilian girl with CPP. This mutation resulted in the substitution of alanine to proline at position 63 (p.A63P) of proneurokinin B (Table 3). The 
Table 3. Variants of TAC3 and TACR3 genes identified in patients with idiopathic central pubertal disorders

\begin{tabular}{|c|c|c|c|c|c|}
\hline Gene & Nucleotide change & Amino acid change & Status & Exon & Phenotype \\
\hline TAC3 & c. $187 \mathrm{G}>\mathrm{C}$ & p.A63P & Heterozygous & 3 & Sporadic CPP \\
\hline \multirow[t]{4}{*}{ TACR3 } & c. $53 \mathrm{G}>\mathrm{A}$ & p.G18D & Heterozygous & 1 & Sporadic $1 \mathrm{HH}$ \\
\hline & c. $[172 \mathrm{C}>\mathrm{T}(;) 824 \mathrm{G}>\mathrm{A}]$ & p.[L58L(;)W275*] & Compound heterozygous & 1 and 3 & Familial IHH \\
\hline & c. $824 \mathrm{G}>\mathrm{A}$ & p.W275* & Homozygous & 3 & Familial IHH \\
\hline & c. $1345 G>T$ & p.A449S & Heterozygous & 5 & Familial CDGP \\
\hline
\end{tabular}

p.A63P variant was absent in the control population of 150 Brazilian patients. In silico analyses suggested that this variant does not alter the splicing sites, but it was predicted to be damaging to the protein (SIFT). However, the pathogenicity of this missense variant was not supported using the Polyphen-2 tool.

The affected girl had pubertal onset at 7 years of age. She had advanced bone age ( 11 years) and breast development pubertal stage Tanner 3. Hormonal evaluation revealed pubertal basal LH level (IFMA) of 1.2 $\mathrm{U} / \mathrm{L}, \mathrm{LH}$ after acute GnRH stimulation (IFMA) of 17.9 U/L, and pubertal basal estrogen level (IFMA) of $35.2 \mathrm{pg} / \mathrm{mL}$. This girl was the only child of nonconsanguineous parents, and segregation analysis revealed that her mother, who had normal pubertal development with menarche at age 12, was also heterozygous for the p.A63P variant, and that her father was homozygous for the wild-type allele.

\section{Normosmic hypogonadotropic hypogonadism}

Analysis of NK3R revealed three known distinct variants p.G18D, p.L58L (c.172C>T) and p.W275* in three unrelated males with normosmic IHH (Table 3 ). All of them were found in heterozygous state, except p.W275*, which was identified in the homozygous state in one IHH patient, and in the heterozygous state in association with the p.L58L (c.172C > T) variant in another. All variants affected highly conserved residues, and were absent in the control group.

The p.G18D variant was identified in a 24 -year-old male. Physical examination showed micropenis, right and left testes $<2.5 \mathrm{~cm}$, and pubic hair Tanner stage II. Hormonal evaluation revealed low basal gonadotropin (IFMA) (LH: $0.8 \mathrm{U} / \mathrm{L}$; FSH: $1.4 \mathrm{U} / \mathrm{L}$ ), and testosterone (IFMA) $(<19 \mathrm{ng} / \mathrm{dL})$ levels. In silico analyses predicted an impact of the p.G18D substitution on protein structure using both PolyPhen and SIFT. Functional analysis of this variant demonstrated the NKB-stimulated fold increases in IP accumulation for WT and G18D NK3R were not significantly different (10).

The p.L58L (c.172C>T) and p.W275* variants were identified in a 20 -year-old male. Physical examination showed right testes of $3.0 \times 0.5 \mathrm{~cm}$ and left testes of $2.0 \times 1.0 \mathrm{~cm}$, and pubic hair Tanner stage III. Hormonal evaluation revealed low gonadotropins (RIA) (LH: $5 \mathrm{U} / \mathrm{L}$; FSH: $9 \mathrm{U} / \mathrm{L}$ ) and testosterone levels (RIA) $(67 \mathrm{ng} / \mathrm{dL})$. Similar cases of absent sexual development in his family were mentioned, but the affected family members were not available for genetic analysis.

Finally, the p.W275* variant in the homozygous state was identified in a 30 -year-old male. Physical examination showed micropenis, right and left testes < $2.0 \times 1.5 \mathrm{~cm}$, and pubic hair Tanner stage III. Hormonal evaluation revealed low basal gonadotropin (IFMA) (LH: < $0.6 \mathrm{U} / \mathrm{L} ; \mathrm{FSH}:<1.0 \mathrm{U} / \mathrm{L}$ ) and testosterone (IFMA) (35 ng/dL) levels. Familial segregation was not available. The mean $( \pm \mathrm{SD}) \mathrm{FSH} / \mathrm{LH}$ ratio of the three IHH patients with TACR 3 variants was $2.40 \pm 1.33$.

\section{Constitutional delay of growth and puberty}

A new heterozygous variant in the TACR3 gene (c. $1345 \mathrm{G}>\mathrm{T}$ ) was identified in a girl with CDGP. This variant resulted in the substitution of alanine to serine at position 449 (p.A449S) of NK3R (Table 3). The p.A449S variant was not identified in any subjects of the control group. Alanine at position 449 is not a conserved residue among all species, and in silico analysis suggested that this variant neither altered a splicing site nor was deleterious to protein structure or function.

The affected girl had pubertal onset at 13.4 years of age, and delayed bone age (11 years). Hormonal evaluation revealed a pre-pubertal basal LH level (IFMA) $0.6 \mathrm{U} / \mathrm{L}$, and a low basal estrogen level (IFMA) 19 $\mathrm{pg} / \mathrm{mL}$. The affected patient reported similar cases in her family, but these relatives were not available for segregation analysis. 


\section{NK3R SNPS}

Three polymorphisms previously described in the NK3R were identified in this cohort of patients. The p.K286R (c.857A $>\mathrm{G})$ variant was identified in $0.9 \%$, $1.4 \%$, and $2 \%$ of patients with CPP, normosmic IHH and CDGP, respectively, and it was not found in any control individual studied. The p.L291L (c.873A >G) variant was identified in $2.6 \%, 1.4 \%$ and $4 \%$ of patients with CPP, normosmic IHH and CDGP, respectively, and it was found in $4 \%$ of control individuals studied. The p.A449T (c.1345G $>$ A) variant was identified in $1.4 \%$ and $4 \%$ of patients with normosmic $\mathrm{IHH}$ and CDGP, respectively, and in $1 \%$ of control individuals studied. Polymorphism frequencies were similar to those previously reported $(20)$.

\section{DISCUSSION}

Complex networks of inhibitory, stimulatory and permissive neuroendocrine factors are involved in the control of puberty onset. Loss-of-function mutations in the TAC3 and TACR 3 genes result in normosmic $\mathrm{IHH}$, characterized by an absence of pubertal development and low circulating levels of LH and gonadal steroids (7-12). A recent study identified rare variants in genes associated with IHH in women with hypothalamic amenorrhea, suggesting that these mutations may also contribute to the variable susceptibility of women to functional changes in GnRH secretion (21). These observations provided compelling evidence for the role of rare variants in common multifactorial diseases (21). In this study, we analyzed the TAC3 and TACR 3 genes in a cohort of patients with central pubertal disorders, including patients with central precocious puberty, normosmic $\mathrm{IHH}$, and constitutional delay of growth and puberty. We described five variants, one in NKB (p.A63P) and four in NK3R (p.Gl8D, p.L58L, p.W275* and p.A449S) in five unrelated patients with central pubertal disorders. All of these variants were absent in the control group, suggesting that they are not common polymorphisms in the Brazilian population.

Activating mutations in KISSI and KISS1R, a G protein-coupled receptor, were previously identified in Brazilian girls with CPP $(18,19)$. Indeed, it is known that $\mathrm{NKB}$ is highly expressed in hypothalamic neurons that also express kisspeptin, and that NKB/NK3R are involved in the regulation of pubertal development (14). Hence, it is also reasonable to hypothesize that gain-of-function mutations in NKB or in NK3R, another $\mathrm{G}$ protein-coupled receptor, might be identified in children with CPP. In this study, a new heterozygous variant (p.A63P) in proneurokinin B was identified in a Brazilian girl with central precocious puberty who had pubertal onset at 7 years of age. TAC3 precursor mRNA contains seven exons, five of which are translated to form the preprotachykinin B peptide. This prepropeptide undergoes enzymatic cleavage to form proneurokinin $\mathrm{B}$, then NKB. Loss-of-function mutations in propeptides have been described in association with several phenotypes (22-24). Activating mutations in propeptides are rare, and no functional studies identifying gain-of-function mutations in propeptides have been described to date. Comparative analysis of the amino acid sequence of neurokinin $B$ showed that the alanine in position 63 is a conserved residue among primates. Nonetheless, this variant was not predicted to alter the splicing site, and the functional effects of this amino acid substitution were controversial using different in silico algorithms.

Recent studies of humans with TAC3 and TACR 3 inactivating mutations provide compelling evidence for the involvement of neurokinin B signaling in human puberty (7-12). In this study, we identified three distinct variants (p.G18D, p.L58L and p.W275*) in NK3R in three unrelated males with IHH who were previously described (10). All of them were heterozygous, except for p.W275*. The p.W275* variant was the most prevalent variant identified in the TACR 3 gene in this Brazilian cohort of patients, as well in the Gianetti and cols. (10) multicenter cohort. Furthermore, heterozygous variants were found in two of three patients with TACR 3 variants. Based on these findings, it is possible that our screening strategy failed to identify mutations in other regions. It is also possible that the heterozygous mutations in TACR 3 do not contribute to the pathogenesis of normosmic $\mathrm{IHH}$, and that only the homozygous mutations have a causative role in IHH. Nevertheless, there are clear precedents for the association of normosmic IHH and Kallmann syndrome with heterozygous mutations in FGF8 and PROK2, which also encode secreted ligands (25-28). Another possibility is that heterozygous TACR 3 mutations act in conjunction with mutations in other genes to cause normosmic IHH, a mechanism previously described in normosmic IHH and Kallmann syndrome $(25,29-31)$.

A high frequency of micropenis was detected in patients with TAC3/TACR 3 variants, indicating NKB/ 
NK3R signaling may be essential for the normal activation of the reproductive axis late in gestation $(7,10$ 12). All IHH patients with TACR 3 variants were in the second decade of life or older, and showed unequivocal evidence of failure of pubertal progression with low circulating sex steroids and prepubertal levels of circulating gonadotropins, and all of them presented with micropenis without cryptorchidism. Recently, dissociation between the very low basal LH and normal or nearly normal basal FSH levels was reported, suggesting the possibility of a specific neuroendocrine impairment and therefore impaired pulsatile delivery of $\mathrm{GnRH}$ in patients with alteration of $\mathrm{NKB}$ signaling $(7,8,12)$. However, this hormonal profile was not observed in our study. IHH Brazilian patients with TACR 3 variants showed similar FSH/LH ratios when compared to other IHH patients with mutations in GNRHR, KISSIR/ GNRH1, KISSIR/PROKR2, PROKR2, FGR1, FGF8, and in IHH patients with no identified genetic variants (data not shown).

Comparative analyses of the amino acid sequences of NK3R showed that these substitutions affected highly conserved residues among all species. In silico analyses were performed, and they suggested that p.G18D variant could be damaging to protein structure, but in vitro studies revealed no significant differences in receptor signaling between wild type and mutant NK3R (10), suggesting that p.G18D variant is not responsible for the IHH phenotype.

Constitutional delay of growth and puberty is, at least in part, genetically determined. Although many genes may be involved with this condition, the inheritance patterns suggest that there are still-to-be-uncovered single genes with major effects (32-34). We hypothesized that mutations in genes underlying IHH might contribute for the pathogenesis of this condition, with incomplete penetrance and/or variable expressivity (33). Recently, mutations in TAC3 or TACR3 genes in patients with $\mathrm{IHH}$ have been associated with high frequency of reversal $\mathrm{IHH}$, a phenotype resembling constitutional delay of growth and puberty (10). Although the NKB/ NK3R complex appear to be clear functional candidates for CDGP, no mutations in the coding region of these system have been described in the literature (33).

In this study, we identified a new heterozygous variant (p.A449S) in NK3R in a Brazilian girl with CDGP who had breast development at 13.4 years of age. Comparative analysis of the amino acid sequence of NK3R showed that alanine at position 449 is not a conserved residue among species. In silico analyses suggested that this substitution did not alter splicing sites (NNSPLICE 0.9 and Human Splicing Finder), neither was damaging to the protein (PolyPhen and SIFT). Taken together, these data did not support a potential role for the p.A449S variant in the CDGP phenotype.

In conclusion, we described new rare variants in the NKB (p.A63P) and in the NK3R (p.A449S) in two girls, one with central precocious puberty and one with constitutional delay of growth and puberty. Our preliminary studies suggested that these two new variants do not seem to have a direct causative role in the precocious puberty and constitutional delay of growth and puberty phenotype. In addition, we identified three known distinct variants (p.G18D, p.L58L, and p.W275X) in the NK3R in three unrelated males with normosmic hypogonadotropic hypogonadism. Finally, we identified a positive association between TAC3 and TACR 3 variants and a normosmic IHH phenotype, indicating that $\mathrm{NKB}$ signaling is required for initiation and normal pubertal development.

Acknowledgements: this study was supported by Fapesp grants 05/04726 and Conselho Nacional de Desenvolvimento Científico e Tecnológico (CNPq) grants 302825/2011-8 (to A.C.L.), by Conselho Nacional de Desenvolvimento Científico e Tecnológico (CNPq) grants 305743/2011-8 (to B.B.M.), and by the Eunice Kennedy Shriver National Institute of Child Health and Human Development, National Institutes of Health (NIH), by means of the cooperative agreement U54 HD28138 as part of the Specialized Cooperative Centers Program in Reproduction and Infertility Research (to U.B.K.).

Disclosure: no potential conflict of interest relevant to this article was reported.

\section{REFERENCES}

1. AlmeidaTA, Rojo J, Nieto PM, Pinto FM, Hernandez M, Martin JD, et al. Tachykinins and tachykinin receptors: structure and activity relationships. Curr Med Chem. 2004;11(15):2045-81.

2. Pennefather JN, Lecci A, Candenas ML, Patak E, Pinto FM, Maggi $\mathrm{CA}$. Tachykinins and tachykinin receptors: a growing family. Life Sci. 2004;74(12):1445-63.

3. Lundberg JM. Pharmacology of cotransmission in the autonomic nervous system: integrative aspects on amines, neuropeptides, adenosine triphosphate, amino acids and nitric oxide. Pharmacol Rev. 1996;48(1):113-78.

4. Pinto FM, Armesto CP, Magraner J, Trujillo M, Martin JD, Candenas ML. Tachykinin receptor and neutral endopeptidase gene expression in the rat uterus: characterization and regulation in response to ovarian steroid treatment. Endocrinology. 1999;140(6):2526-32.

5. Zagorodnyuk V, Maggi CA. Tachykinin NK1 and NK2 receptors mediate non-adrenergic non-cholinergic excitatory neuromus- 
cular transmission in the guinea-pig stomach. Neuroscience. 1997;80(2):625-34.

6. Page NM, Woods RJ, Lowry PJ. A regulatory role for neurokinin $B$ in placental physiology and pre-eclampsia. Regul Pept. 2001;98(3):97-104.

7. Topaloglu AK, Reimann F, Guclu M, Yalin AS, Kotan LD, Porter KM, et al. TAC3 and TACR3 mutations in familial hypogonadotropic hypogonadism reveal a key role for Neurokinin B in the central control of reproduction. Nat Genet. 2009;41(3):354-8.

8. Francou B, Bouligand J, Voican A, Amazit L, Trabado S, Fagart J, et al. Normosmic congenital hypogonadotropic hypogonadism due to TAC3/TACR3 mutations: characterization of neuroendocrine phenotypes and novel mutations. PLoS One. 2011;6(10):e25614.

9. Fukami M, Maruyama T, Dateki S, Sato N, Yoshimura Y, Ogata T. Hypothalamic dysfunction in a female with isolated hypogonadotropic hypogonadism and compound heterozygous TACR3 mutations and clinical manifestation in her heterozygous mother. Horm Res Paediatr. 2010;73(6):477-81.

10. Gianetti E, Tusset C, Noel SD, Au MG, Dwyer AA, Hughes VA, et al. TAC3/TACR3 mutations reveal preferential activation of gonadotropin-releasing hormone release by neurokinin $B$ in neonatal life followed by reversal in adulthood. J Clin Endocrinol Metab. 2010;95(6):2857-67.

11. Guran T, Tolhurst G, Bereket A, Rocha N, Porter K, Turan S, et al. Hypogonadotropic hypogonadism due to a novel missense mutation in the first extracellular loop of the neurokinin B receptor. $J$ Clin Endocrinol Metab. 2009;94(10):3633-9.

12. Young J, Bouligand J, Francou B, Raffin-Sanson ML, Gaillez S, Jeanpierre M, et al.TAC3 andTACR3 defects cause hypothalamic congenital hypogonadotropic hypogonadism in humans. J Clin Endocrinol Metab. 2010;95(5):2287-95.

13. Latronico AC. The neurokinin B pathway in human reproduction. Nat Genet. 2009;41(3):269-70.

14. Goodman RL, Lehman MN, Smith JT, Coolen LM, de Oliveira CV, Jafarzadehshirazi MR, et al. Kisspeptin neurons in the arcuate nucleus of the ewe express both dynorphin $A$ and neurokinin B. Endocrinology. 2007;148(12):5752-60.

15. Krajewski SJ, Burke MC, Anderson MJ, McMullen NT, Rance NE. Forebrain projections of arcuate neurokinin $B$ neurons demonstrated by anterograde tract-tracing and monosodium glutamate lesions in the rat. Neuroscience. 2010;166(2):680-97.

16. Navarro VM, Gottsch ML, Chavkin C, Okamura H, Clifton DK, Steiner RA. Regulation of gonadotropin-releasing hormone secretion by kisspeptin/dynorphin/neurokinin B neurons in the arcuate nucleus of the mouse. J Neurosci. 2009;29(38):11859-66.

17. Seminara SB. Mechanisms of disease: the first kiss-a crucial role for kisspeptin-1 and its receptor, G-protein-coupled receptor 54, in puberty and reproduction. Nat Clin Pract Endocrinol Metab. 2006;2(6):328-34.

18. Teles MG, Bianco SD, Brito VN, Trarbach EB, Kuohung W, Xu S, et al. A GPR54-activating mutation in a patient with central precocious puberty. N Engl J Med. 2008;358(7):709-15.

19. Silveira LG, Noel SD, Silveira-Neto AP, Abreu AP, Brito VN, Santos $M G$, et al. Mutations of the KISS1 gene in disorders of puberty. J Clin Endocrinol Metab. 2010;95(5):2276-80.
20. Foroud T, Wetherill LF, Kramer J, Tischfield JA, Nurnberger JI Jr., Schuckit MA, et al. The tachykinin receptor 3 is associated with alcohol and cocaine dependence. Alcohol Clin Exp Res. 2008;32(6):1023-30.

21. Caronia LM, Martin C, Welt CK, Sykiotis GP, Quinton R, Thambun$\operatorname{dit} A$, et al. A genetic basis for functional hypothalamic amenorrhea. N Engl J Med. 2011;364(3):215-25.

22. Jahns $M$, Friess $D$, Demarmels Biasiutti $F$, Kremer Hovinga JA, Alberio $\mathrm{L}$, Oldenburg $\mathrm{J}$, et al. Massive muscle haematoma three months after starting vitamin $\mathrm{K}$ antagonist therapy for deep-vein thrombosis in an antithrombin deficient patient: another case of factor IX propeptide mutation. Thromb Haemost. 2011;106(2):381-2.

23. Kannu P, O'Rielly DD, Hyland JC, Kokko LA. Avascular necrosis of the femoral head due to a novel $\mathrm{C}$ propeptide mutation in COL2A1. Am J Med Genet A. 2011;155(7):1759-62.

24. Symoens $S$, Malfait $F$, Vlummens $P$, Hermanns-Le $T$, Syx $D$, De Paepe A. A novel splice variant in the N-propeptide of COL5A1 causes an EDS phenotype with severe kyphoscoliosis and eye involvement. PLoS One. 2011;6(5):e20121.

25. Dode C, Teixeira L, Levilliers J, Fouveaut C, Bouchard P, Kottler $\mathrm{ML}$, et al. Kallmann syndrome: mutations in the genes encoding prokineticin-2 and prokineticin receptor-2. PLoS Genet. 2006;2(10):e175.

26. Falardeau J, Chung WC, Beenken A, Raivio T, Plummer L, Sidis $Y$, et al. Decreased FGF8 signaling causes deficiency of gonadotropin-releasing hormone in humans and mice. J Clin Invest. 2008;118(8):2822-31.

27. Gajdos ZK, Hirschhorn JN, Palmert MR. What controls the timing of puberty? An update on progress from genetic investigation. Curr Opin Endocrinol Diabetes Obes. 2009;16(1):16-24.

28. Kim HG, Bhagavath B, Layman LC. Clinical manifestations of impaired $\mathrm{GnRH}$ neuron development and function. Neurosignals. 2008;16(2-3):165-82.

29. Canto P, Munguia P, Soderlund D, Castro JJ, Mendez JP. Genetic analysis in patients with Kallmann syndrome: coexistence of mutations in prokineticin receptor 2 and KAL1. J Androl. 2009;30(1):41-5.

30. Pitteloud N, Quinton R, Pearce S, RaivioT, Acierno J, Dwyer A, et al. Digenic mutations account for variable phenotypes in idiopathic hypogonadotropic hypogonadism. J Clin Invest. 2007;117(2):457-63.

31. Pitteloud N, Zhang C, Pignatelli D, Li JD, Raivio T, Cole LW, et al. Loss-of-function mutation in the prokineticin 2 gene causes Kallmann syndrome and normosmic idiopathic hypogonadotropic hypogonadism. Proc Natl Acad Sci U S A. 2007;104(44):17447-52.

32. Sedlmeyer IL, Hirschhorn JN, Palmert MR. Pedigree analysis of constitutional delay of growth and maturation: determination of familial aggregation and inheritance patterns. J Clin Endocrinol Metab. 2002;87(12):5581-6.

33. Vaaralahti K, Wehkalampi K, Tommiska J, Laitinen EM, Dunkel L, Raivio $T$. The role of gene defects underlying isolated hypogonadotropic hypogonadism in patients with constitutional delay of growth and puberty. Fertil Steril. 2011;95(8):2756-8.

34. Wehkalampi K, Widen E, Laine T, Palotie A, Dunkel L. Patterns of inheritance of constitutional delay of growth and puberty in families of adolescent girls and boys referred to specialist pediatric care. J Clin Endocrinol Metab. 2008;93(3):723-8. 